\title{
Kecernaan Ransum yang Mengandung Limbah Roti pada Domba
}

\section{Shiyami Asri Yamashita, Rani Darliani Rachmat, Ana Rochana Tarmidi, Budi Ayuningsih, Iman Hernaman*}

\author{
Fakultas Peternakan Universitas Padjadjaran \\ Jl. Raya Bandung Sumedang Km 21 Jatinangor Sumedang 45363 \\ "Email korespondensi: iman.hernaman@unpad.ac.id
}

(Diterima 01-12-2019; disetujui 27-12-2019)

\begin{abstract}
ABSTRAK
Limbah roti memiliki potensi sebagai pakan untuk domba, namun belum banyak diketahui dampaknya terhadap kecernaan. Penelitian bertujuan untuk menguji ransum yang mengandung limbah roti terhadap kecernaan pada domba. Dua puluh ekor domba lokal dengan bobot hidup 34,65 $\pm 2,87 \mathrm{~kg}$ dialokasikan ke dalam 5 ransum perlakuan yang mengandung limbah roti sebanyak $0,6,12,18$, dan $24 \%$. Penelitian dilaksanakan secara eksmperimental dengan menggunakan rancangan acak lengkap. Data yang terkumpul dianalisis dengan sidik ragam. Hasil menunjukan bahwa penggunaan limbah roti sampai $24 \%$ dalam ransum tidak berpengaruh terhadap kecernaan protein kasar, lemak kasar, bahan kering dan bahan organik dengan nilai rataan berturut-turut $54,91 \%, 73,39 \%, 66,80 \%$ dan $69,86 \%$. Kesimpulan, limbah roti dapat digunakan dalam ransum sampai $24 \%$ dan tidak menganggu kecernaan pada domba.
\end{abstract}

Kata kunci: domba, kecernaan, limbah, ransum, roti

\section{ABSTRACT}

Bread waste has potential as a feed for sheep, but not yet known the impact on digestibility. The research aims to test the ration containing bread waste on digestibility in sheep. Twenty local sheep with a body weight of $34.65 \pm 2.87 \mathrm{~kg}$ were allocated into 5 treatment rations containing bread waste of $0,6,12.18$, and $24 \%$. The study was conducted experimentally using a completely randomized design. The data collected was analyzed by variance. The results showed that the use of bread waste up to $24 \%$ in the ration did not affect the digestibility of crude protein, crude fat, dry matter and organic matter with an average value of $54.91 \%, 73.39 \%, 66.80 \%$ and $69.86 \%$. Conclusion, bread waste can be used in rations up to $24 \%$ and does not interfere with digestibility in sheep.

Keywords: sheep, digestibility, waste, ration, bread

\section{PENDAHULUAN}

Industri roti di Indonesia tumbuh $10 \%$ setiap tahunnya dan menyisakan $25 \%$ produksinya yang terbuang atau tidak terjual sebagai limbah. Limbah ini merupakan bahan pakan alternatif potensial yang dapat dimanfaatkan sebagai pakan ternak, khususnya untuk ternak ruminansia. Limbah roti merupakan roti yang tidak layak atau telah kadaluarsa menurut ketentuan waktu yang telah ditentukan sehingga ditarik dari pasaran. Makanan kadaluarsa tidak boleh dikonsumsi oleh manusia karena telah melampaui batas waktu yang ditentukan (Jayani \& Pudjihardjo, 2013).

Hasil analisis menunjukan bahwa kandungan nutrien limbah roti sebesar $13,56 \%$ protein kasar, 8,55\% lemak kasar, 5,86\% serat kasar, $46,83 \%$ bahan ekstrak tanpa nitrogen (BETN),
2,5\% abu dan $68,74 \%$ total digestible nutrient (TDN). Kandungan nutrien tersebut menunjukan bahwa limbah roti rendah serat kasar dengan protein yang cukup tinggi hampir setara dengan dedak padi sebesar 11,3-14,44\%, (Lubis et al., 2002). Melihat nutriennya, maka limbah roti dapat dikatakan sebagai bahan pakan sumber energi (Hartadi et al., 2005). Sebagai pangan, roti aman untuk dikonsumsi, tidak mengandung anti nutrisi atau racun, kecuali jika tumbuh jamur (Mizana et al., 2016).

Roti berasal dari tepung terigu hasil dari penggilingan biji gandum. Tepung terigu mengandung banyak zat pati, yaitu karbohidrat kompleks yang tidak larut dalam air, juga mengandung protein dalam bentuk gluten (Pusuma et al., 2018). Karbohidrat dan protein difermentasi oleh mikroba rumen yang memiliki kemampuan 
untuk mencerna zat-zat makanan yang masuk ke dalam rumen dan diperkirakan $70-80 \%$ bahan pakan yang dikonsumsi dicerna dengan bantuan mikroba rumen (Banerjee, 1978). Penelitian bertujuan untuk menguji penggunaan limbah roti dalam ransum terhadap kecernaan pada domba.

\section{MATERI DAN METODE}

\section{Materi Penelitian}

Penelitian ini menggunakan 20 ekor domba lokal jantan dengan bobot hidup $34,65 \pm 2,87 \mathrm{~kg}$, pakan yang digunakan yaitu umput lapangan, dedak padi, bungkil kelapa, ampas kecap, dan limbah roti.

\section{Metode Penelitian}

Metode penelitian menggunakan rancangan acak lengkap (RAL) dengan menggunakan 5 macam ransum perlakuan (Tabel 1) yang mengandung limbah roti sebanyak 0 (T0), 6 (T1), 12 (T2), 18 (T3), 24 (T4) \% dari bahan kering. Masing-masing perlakuan diulang sebanyak 4 kali.

\section{Prosedur Penelitian}

Domba tersebut dimasukan ke dalam kandang individu dengan konstruksi kandang panggung terbuat dari kayu dan beralaskan bilah bambu dengan atap genting. Pemberian ransum dilakukan dua kali sehari pada pukul 09.00 dan 15.00. Ransum terdiri atas rumput lapangan dan konsentrat dengan perbandingan $40 \%$ dan $60 \%$. Konsentrat terdiri atas, ampas kecap, bungkil kelapa, onggok, dedak padi limbah roti sebagai bahan pakan yang diuji. Rumput lapangan diambil dari kawasan Agroteknobisnis Sumedang. Limbah roti diperoleh dari PT. Multistar Majalaya Kabupaten Bandung, sedangkan bahan baku konsentrat lainnya berasal dari KSU Tandangsari, Kabupaten Sumedang. Air minum diberikan secara ad libitum dengan menggunakan ember yang disimpan di setiap kandang. Ransum disusun iso proten dan iso energy yaitu $10,48 \%$ dan 65,81 $67,35 \%$.

\section{Variabel Penelitian}

Setelah ternak masuk ke dalam kandang individu lalu diadaptasikan dengan lingkungan kandang dan setelah itu melakukan adaptasi ransum perlakuan selama 7 hari. Perhitungan konsumsi ransum dan penampungan feses dilakukan setiap hari selama 7 hari setelah beradaptasi dengan ransum perlakuan. Feses yang terkumpul disemprot dengan asam borat $5 \%$ untuk mencegah penguapan nitrogen. Feses diambil 10\% dari total feses serta dikeringkan dengan cara dijemur. Seluruh sampel feses yang telah kering dikumpulkan menjadi satu dan diaduk hingga rata kemudian dilakukan analisis proksimat meliputi kandungan bahan kering dan organik serta nutriennya meliputi protein kasar dan lemak kasar (AOAC, 2005). Data konsumsi dan kandungan nutrien feses, kemudian digunakan untuk menghitung kecernaan sebagai berikut:

$$
\begin{aligned}
& \text { Kecernaan Protein Kasar }(\mathrm{PK})=\frac{\text { Konsumsi PK }- \text { PK Feses }}{P K \text { Feses }} \times 100 \% \\
& \text { Kecernaan Lemak Kasar }(\mathrm{LK})=\frac{\text { Konsumsi LK }- \text { LK Feses }}{\text { LK Feses }} \times 100 \% \\
& \text { Kecernaan Bahan Kering }(\mathrm{BK})=\frac{\text { Konsumsi BK }- \text { BK Feses }}{\text { BK Feses }} \times 100 \% \\
& \text { Kecernaan Bahan Organik }(\mathrm{BO})=\frac{\text { Konsumsi BO }- \text { BO Feses }}{\text { BO Feses }} \times 100
\end{aligned}
$$

\section{Analisis Data}

Data yang terkumpul dianalisis dengan sidik ragam pada taraf $5 \%(\mathrm{P}<0,05)$ (Steel \& Torie, 1995).

Tabel 1. Susunan bahan pakan dan kandungan nutrien ransum percobaan

\begin{tabular}{lccccc}
\hline Bahan Pakan & T0 & T1 & T2 & T3 & T4 \\
\hline Rumput Lapangan (\%) & 40,00 & 40,00 & 40,00 & 40,00 & 40,00 \\
Konsentrat : & 60,00 & 60,00 & 60,00 & 60,00 & 60,00 \\
$\quad$ Dedak Padi (\%) & 24,00 & 24,00 & 24,00 & 23,09 & 10,47 \\
$\quad$ Onggok (\%) & 19,23 & 16,72 & 14,21 & 12,11 & 15,29 \\
$\quad$ Bungkil Kelapa (\%) & 10,01 & 7,57 & 5,13 & 3,00 & 4,92 \\
$\quad$ Ampas Kecap (\%) & 6,75 & 5,71 & 4,66 & 3,80 & 5,32 \\
$\quad$ Limbah Roti (\%) & 0,00 & 6,00 & 12,00 & 18,00 & 24,00 \\
\hline Total & 100,00 & 100,00 & 100,00 & 100,00 & 100,00 \\
\hline Kandungan Zat Makanan & & & & & \\
Protein Kasar (\%) & 10,48 & 10,48 & 10,48 & 10,48 & 10,48 \\
Lemak Kasar (\%) & 5,38 & 5,38 & 5,38 & 5,38 & 5,38 \\
Serat Kasar (\%) & 20,23 & 19,84 & 19,46 & 19,06 & 18,45 \\
Bahan Ekstrak Tanpa Nitrogen (BETN) & 52,61 & 51,89 & 51,17 & 50,53 & 50,89 \\
Abu (\%) & 11,31 & 12,41 & 13,52 & 14,55 & 14,80 \\
Total Digestible Nutrien/TDN (\%) & 67,35 & 66,81 & 66,27 & 65,81 & 66,35 \\
\hline Ketergand : Kan
\end{tabular}

Keterangan : Kandungan nutrien ransum perlakuan didasarkan pada perhitungan dan $100 \%$ bahan kering (BK) 


\section{HASIL DAN PEMBAHASAN}

Pencernaan adalah serangakaian proses yang terjadi di dalam alat pencernaan sampai memungkinkan terjadinya penyerapan. Proses tersebut merupakan suatu perubahan fisik dan kimia yang dialami oleh bahan pakan dalam alat pencernaan. Pencernaan pada ternak ruminansia merupakan proses yang sangat kompleks yang melibatkan interaksi dinamis antara pakan, populasi mikroba dan ternak itu sendiri (Martens, 1993). Kecernaan suatu bahan pakan atau ransum akan berbeda satu dengan yang lain. Kecernaan dipengaruhi oleh spesies, bentuk fisik, komposisi bahan, tingkat pemberian pakan dan temperatur lingkungan (Ranjhan, 1977).

Hasil analisis sidik ragam menunjukkan bahwa penggunaan limbah roti dalam ransum tidak mempengaruhi kecernaan protein kasar, kecernaan lemak kasar, kecernaan bahan kering, dan kecernaan bahan organik. Hal ini menunjukan bahwa penggunaan limbah roti sampai $24 \%$ tidak membri pengaruh terhadap kecernaan. Kecernaan protein kasar dan lemak kasar berkisar 50,4860,40\% (rataan 54,91\%) dan 68,46-77,23\% (rataan 73,39\%), sedangkan kecernaan bahan kering dan organik berkisar $62,58-72,04 \%$ (rataan $66,80 \%$ ) dan $66,65-74,41 \%$ (rataan $69,86 \%$ ).

Kecernaan lemak kasar pada pada penelitian ini lebih tinggi dibandingkan dengan kecernaan protein $(54,91$ vs $73,39 \%)$. Hal ini disebabkan struktur kimia lemak yang mudah dicerna dibandingkan dengan protein (Wiseman, 1990). Teti et al., (2018) menjelaskan bahwa Kemampuan untuk menyerap dan mencerna lemak meningkat tinggi jika: lebih banyak mengandung (1) ikatan lemak rantai pendek, (2) asam lemak tidak jenuh, dan (3) trigliserida daripada asam lemak bebas.

Kecernaan bahan kering dan bahan organik hasil penelitian rata-rata lebih tinggi dibandingkan dengan hasil penelitian Schneider \& Flatt (1975) dan Gatenby (1986) berturut-turut, yaitu sebesar $50,7-59,7 \%$ serta $57,3-63,0 \%$, perbedaan ini disebabkan karena ransum yang diberikan serta domba yang digunakan berbeda. Setiap jenis pakan memiliki karakteristik komposisi kimia yang berbeda sehingga proses pencernaan di dalam tubuh ternak juga berbeda. Demikian pula dengan jenis ternak, kemampuan adaptasi terhadap jenis ransum dan karakteristik mikroba yang yang dipunyai dari ternak tersebut berbeda di setiap tempat, meskipun pada jenis ternak yang sama. Hal ini berdampak pada kecernaan yang berbeda.

Kecernaan bahan organik lebih tinggi dibandingkan dengan kecernaan bahan kering (66,8 vs $69,86 \%)$. Hal ini karena kecernaan bahan organik terdiri atas kecernaan karbohidrat, protein, lemak dan vitamin yang secara umum lebih mudah dicerna. Kecernaan bahan organik tidak melibatkan bahan anorganik (abu). Kecernaan bahan organik dapat dipengaruhi oleh kandungan abu. Jika kandungan abu tinggi akan mengakibatkan kandungan bahan organik menjadi lebih rendah. Kandungan abu dalam ransum (Tabel 1) relatif rendah oleh sebab itu kecernaan bahan organiknya lebih tinggidibandingkan dengan bahan organik.

Kecernaan yang tidak berbeda nyata disebabkan karena kandungan nutrient terutama protein kasar dan energy (TDN) pada masing masing perlakuan adalah sama (Tabel 1). Dua unsur tersebut dalam ransum berpengaruh terhadap kecernaan. Kecernaan pada ternak ruminansia tidak akan terlepas dari peranan mikroba rumen. Untuk berkembang dan beraktifitas dalam mencerna, mikroba rumen membutuhkan $\mathrm{N}$ hasil perombakan ptotein dalam ransum. Oktarina et al., (2004) menyatakan bahwa terdapat hubungan anatara ketersediaan protein dalam ransum dengan perkembangbiakan dan populasi mikrobia rumen. Peningkatan populasi mikroba akan meningkatkan pula konsentrasi enzim yang dihasilkan yang berperan dalam proses pencernaan pakan. Selain protein, energi sangat menentukan kecernaan ransum. Energi yang dihasilkan dari proses degradasi nutrien akan digunakan untuk mendukung pertumbuhan populasi mikroba rumen yang sangat berperan dalam mencerna pakan.

Limbah roti yang digunakan memiliki komposisi nutrien yang mudah dicerna, Oleh karena itu, meskipun digunakan sampai taraf $24 \%$, limbah roti memberikan hasil yang sama terhadap kecernaan. Roti merupakan makanan yang kaya dengan dengan pati, rendah serat kasar dan mengandung protein, selain itu juga diperkaya dengan gula, mineral dan bahan-bahan yang dapat meningkatkan kualitas roti (Mustika et al., 2015).

Tabel 2. Pengaruh perlakuan terhadap kecernaan

\begin{tabular}{lccccc}
\hline \multicolumn{1}{c}{ Peubah } & T0 & T1 & T2 & T3 & T4 \\
\hline Kecernaan Protein Kasar (\%) & $60,40 \pm 9,41$ & $50,48 \pm 9,53$ & $51,15 \pm 11,94$ & $52,65 \pm 6,83$ & $60,24 \pm 6,96$ \\
Kecernaan Lemak Kasar (\%) & $73,83 \pm 10,44$ & $68,46 \pm 2,71$ & $75,35 \pm 6,64$ & $72,07 \pm 8,78$ & $77,23 \pm 7,72$ \\
Kecernaan Bahan Kering (\%) & $69,25 \pm 8,22$ & $62,58 \pm 4,57$ & $64,96 \pm 8,79$ & $65,16 \pm 4,35$ & $72,04 \pm 4,59$ \\
Kecernaan Bahan Organik (\%) & $73,30 \pm 7,61$ & $66,65 \pm 3,78$ & $67,78 \pm 7,96$ & $67,16 \pm 4,48$ & $74,41 \pm 4,06$ \\
\hline
\end{tabular}


Nutrien tersebut akan mendukung bagi perkembangan mikroba rumen pencerna pakan. Tillman et al. (1998) menyatakan bahwa daya cerna berhubungan dengan komposisi kimia pakan dan serat kasar mempunyai pengaruh yang terbesar terhdap daya cerna,

Limbah roti yang digunakan merupakan hasil pengolahan. Sebelum digunakan limbah roti dikeringkan terlebih dahulu lalu digiling halus. Pengolahan menyebabkan komponen-komponen nutrien yang komplek berubah menjadi komponen yang lebih sederhana dan mudah dicerna. Menurut Parakkasi (1999) bahwa struktur atau bentuk partikel yang lebih sederhana menyebabkan kecepatan pakan atau laju cerna pakan dalam saluran pencernaan menjadi cepat sehingga banyak nutrien yang tercerna. Roti sebagai makanan manusia tentunya aman dikonsumsi manusia, tidak mengandung racun maupun antinutrisi. Racun maupun antinutrisi akan menganggu metabolisme dalam tubuh (Suryani et al., 2009) termasuk dalam proses pencernaan. Oleh karena itu, penggunaan limbah roti tidak akan berdampak terhadap kecernaan.

\section{KESIMPULAN}

Limbah roti dapat digunakan dalam ransum sampai $24 \%$ dan tidak menganggu kecernaan pada domba.

\section{UCAPAN TERIMAKASIH}

Terimakasih disampaikan pada Kawasan Agroteknobisinis Sumedang dan PT Multistar atas dukungan penyedian sarana dan prasarana penelitian serta Laboratorium Nutrisi Ternak Ruminansia dan Kimia Makanan Ternak yang telah membantu dalam analisis proksimat.

\section{DAFTAR PUSTAKA}

AOAC. 2005. Official Methods of Analysis. $18^{\text {th }}$ ed. Association of Official Agricultural Chemists. Washington, DC.

Banerjee, G.C. 1978. Animal Nutrition. Oxford \& IBM Pub. Co Calcutta.

Gatenby, R.M. 1986. Sheep Production in the Tropics and Sub Tropics. Edisi ke-1. Longman inc., New York.

Hartadi, H.S. Reksohadiprodjo, \& A.D. Tillman. 2005. Tabel Komposisi Pakan untuk Indonesia. Cetakan ke-5. Gadjah Mada University Press. Yogyakarta.
Jayani, S.N. \& W.J. Pudjihardjo. 2013. Faktor penyebab stagnant dan stockout bahan makanan kering di instalasi gizi RSUD Bhakti Dharma Husada Surabaya. Jurnal Administrasi Kesehatan Indonesia (1):280290.

Lubis, S., R. Rachmat, Sudaryono, \& S. Nugraha. 2002. Pengawetan dedak dengan metode inkubasi. Balitpa Sukamandi. Kerawang

Martens, D.R. 1993. Rate and extent of digestion. In Quantitaive Aspect of Ruminant Digestion and Metabolisme. Forbes, J.M. \& J. Frence (editor). CAB International. Canada.

Mizana, D.K., N. Suharti, \& A. Amir. 2016. Identifikasi pertumbuhan jamur aspergillus sp pada roti tawar yang dijual di kota padang berdasarkan suhu dan lama penyimpanan. Jurnal Kesehatan Andalas 5(2):355-360.

Mustika. A.S., L. Kurniawati, \& A. Mustofa. 2015. Karakteristik roti tawar dengan substitusi tepung sorgum (Sorghum bicolor (1) Moench) terfermentasi dan tanpa fermentasi. Jurnal Teknologi Hasil Pertanian $8(1): 1-5$.

Oktarina, K., E. Rianto, R. Adiwinarti, \& A. Purnomoadi. 2004. Retensi protein pada Domba Ekor Tipis jantan yang mendapat pakan penguat dedak padi dengan aras yang berbeda. J Pengembangan Peternakan Tropis Spec Ed 1:110-115.

Parakkasi, A. 1999. Ilmu Nutrisi dan Makanan Ternak Ruminan. Cetakan Pertama. Penerbit Universitas Indonesia. Jakarta.

Pusuma, D.P., Y. Praptiningsih, \& M. Choiron. 2018. Karakteristik roti tawar kaya serat yang disubstitusi menggunakan tepung ampas kelapa. Jurnal Agroteknologi 12 (1):29-42.

Ranjhan, S. K. 1977. Animal Nutrition. $3^{\text {rd }}$ Ed. Vikas Publishing House. New Delhi.

Steel, R.G.D. \& J.H. Torrie. 1995. Prinsip dan Prosedur Statistika Suatu Pendekatan Biometrik. Cetakan ke-4. PT. Gramedia Pustaka Utama. Jakarta.

Suryani, S., I. Nurjanah, \& I. Hernaman. 2009. penyerapan timbal $(\mathrm{Pb})$ pada mencit (Mus musculus) yang diberi daun putri malu (Mimosa pudica L.) dalam Ransum. Biotika 7(1):8-14. 
Schneider, B.H \& W. P. Flatt. 1975. Evaluation of Feed Trough Digestibility. The University of Georgia, Athens, G.A.

Teti, N., R. Latvia, I. Hernaman, B. Ayuningsih, D. Ramdani, \& Siswoyo. 2018. Pengaruh imbangan protein dan energi terhadap kecernaan nutrien ransum domba garut betina. JITP 6 (2):97-101.
Tillman, A.D., H. Hartadi, S. Reksohadiprojo, S. Prawirokusumo, \& S. Lebdosoekojo. 1998. Ilmu Makanan Ternak Dasar. Edisi Keenam. Gadjah Mada University Press. Yogyakarta.

Wiseman, J. 1990. Variability in the Nutritive Value of Fats for Ruminant. Butterworths. London. 